\title{
Illegal bird hunting in the Maltese Islands: an international perspective
}

\author{
André F. Raine, Mark Gauci and Nicholas Barbara
}

\begin{abstract}
Illegal hunting is a widespread problem in the Maltese Islands. As well as having a significant impact on the islands' breeding birds, the illegal hunting of migratory birds has a wider, international dimension. To investigate the international impact of illegal hunting in Malta we considered the entire ring recovery database of the Valletta Bird Ringing Scheme, from the 1920 s to the present. All records of birds that were ringed overseas and shot by hunters in Malta were analysed, comprising a total of 435 records of 84 species from 36 countries. The majority of these ring recoveries (91.7\%) were from species listed as protected and non-huntable throughout the European Union, with a significant proportion listed as European Species of Conservation Concern. Birds of prey were particularly represented in the database, $78.6 \%$ of which were ringed as nestlings or juveniles, highlighting the impact of illegal hunting on this group of species in particular. Species targeted illegally by Maltese hunters originate from countries throughout Europe and Africa, particularly Finland, Sweden, Tunisia, Italy and Germany. For rare species or those with small breeding populations in affected countries, illegal hunting could therefore have a significant impact on the long-term persistence of European populations. Poaching of species such as the pallid harrier Circus macrourus and saker falcon Falco cherrug could have a global impact on their populations.
\end{abstract}

Keywords BirdLife Malta, bird ringing, illegal hunting, Malta, migration, raptors

\section{Introduction}

$T$ he Maltese Islands lie along the central route of the 1 European-African migratory flyway and are an important stepping stone for birds migrating between European breeding grounds and African wintering grounds. The islands represent a vital stop-over and refuelling site for the birds to replenish fat stores for onwards migration (Sultana \& Gauci, 1982; Raine, 2011), particularly during bad weather, and are also an important overnight roost site for larger migrating birds (e.g. birds of prey, herons

AndRÉ F. RaInE (Corresponding author) Kaua'i Endangered Seabird Recovery Project, PO Box 81, Hanapepe 96741, Hawaii, USA. E-mail araine6@hawaii.edu

Mark Gauci and Nicholas Barbara BirdLife Malta, Ta'Xbiex XBX 1120, Malta

Received 18 January 2015. Revision requested 26 February 2015.

Accepted 18 March 2015. First published online 9 September 2015. and storks). More than 170 species use Malta during the spring and autumn migration periods (Sultana \& Gauci, 1982; Casha, 2004; Raine, 2011).

The Maltese Islands have developed a notorious reputation for uncontrolled illegal hunting activities, which are widespread throughout the main islands of Malta and Gozo, with hunters targeting the majority of bird taxa, from raptors, herons and storks to migrating passerines and hirundines. BirdLife Malta records thousands of incidents of illegal hunting and trapping annually (Raine \& Temuge, 2009, 2010; Raine, 2011; BirdLife Malta, 2014), including hundreds of reports of hunters targeting protected species, and video evidence is passed on to local law enforcement agents as well as the European Commission. Illegal hunting in Malta has also received significant media attention, both locally and internationally. Recent examples of the scale of the problem include the massacre of a flock of white storks Ciconia ciconia in May 2011 (BirdLife International, 2011), the killing of at least 14 individuals of a mixed flock of booted eagles Hieraaetus pennatus, lesser spotted eagles Clanga pomarina and short-toed eagles Circaetus gallicus on a single day in October 2013 (Gozo News, 2013), the systematic killing of black storks Ciconia nigra (BirdLife Malta, 2013a; Times of Malta, 2013) and the targeting of white storks at the start of the 2014 autumn hunting season. The latter event resulted in the killing of at least one stork from an Italian reintroduction effort and led to the temporary and unprecedented closure of the autumn hunting season that year (Malta Today, 2014a); several ornithologists and journalists were injured in the ensuing violent protests by hunters (Times of Malta, 2014a,b).

Illegal hunting has also resulted in the extirpation of a number of Maltese bird species and has prevented their reestablishment in recent years (Raine et al., 2009; Raine, 2011; Sultana et al., 2011). These include the western jackdaw Corvus monedula (the last individual was shot in Gozo in 1956; Sultana \& Gauci, 1982), the barn owl Tyto alba, (the last breeding pair was shot in 1988; Fenech \& Balzan, 1988), and the peregrine falcon Falco peregrinus (the last confirmed breeding pair was shot in Ta' Cenc in 1982; Sultana \& Gauci, 1983). Peregrine falcons in particular pass over the Maltese Islands each year on migration and sometimes attempt to nest, but the persecution of these species prevents them from reestablishing despite available breeding habitat and prey (Raine et al., 2009; Sultana et al., 2011). Peregrine falcons are particularly prized and are targeted using decoys, live pigeons as 
lures, and speedboats to access potential nesting areas on cliffs (Raine, 2011).

Reports of illegal hunting span the whole year and occur countrywide. A significant proportion of the country's 10,811 registered hunters (figures for the 2014 autumn hunting season; WBRU, 2015) are involved as well as an unknown number of unregistered hunters. These incidents are well documented by both BirdLife Malta and the Committee Against Bird Slaughter (a German conservation organization operating on the islands during peak migration periods), and video evidence is presented on their websites.

Since 1965 licensed bird ringers have been carrying out scientific studies and bird monitoring work on the Maltese Islands through the Valletta Bird Ringing Scheme (administered by BirdLife Malta). This work has helped to document Malta's significance as a migratory stepping stone in the Mediterranean, as the collection of data on international ring recoveries identifies the European or African origins of species passing over the Maltese Islands in spring and autumn. This analysis aims to investigate the international impact of illegal hunting in Malta by considering the database records that relate to birds shot and killed by Maltese hunters.

\section{Methods}

The entire ring recovery database of the Valletta Bird Ringing Scheme was considered initially, comprising 1,486 records from the 1920 s until October 2014. Ring recoveries were categorized as (1) recaptured and released by licensed ringers, (2) resighted in the field, (3) brought in dead or wounded by members of the public, (4) killed by hunters, or (5) trapped by trappers and not released.

Only those killed by hunters (category 4) were considered in the analysis, along with records from category 3 where the cause of injury was confirmed by an independent veterinarian as gunshot. Records in category 4 included rings that were shown by the hunters themselves to members of BirdLife Malta, rings that were handed over to the Natural History Museum of Malta from hunters' taxidermy collections, those from illegal taxidermy collections confiscated by the police, and rings retrieved from birds that were shot by hunters and recovered by the police, BirdLife Malta or other NGOs.

Prior to 1911 there were no protected species in Malta and any bird could be shot legally. With Government Notice 25 in 1911 a number of species were protected but it was not until Legal Notice 68 was published in 1980 that all species apart from 21 legally huntable species and 15 trappable species were officially protected. Some of the species protected in Europe and shot in Malta prior to 1980 would therefore have been shot legally. Nonetheless, as all of these species are still targeted in Malta despite being protected it is valid to consider all of the ring recoveries pertaining to birds being shot in the wider context of this analysis.

\section{Results}

A total of 435 records in the database relate to birds that were ringed overseas and shot in Malta during 1920-2014, representing 36 countries (Fig. 1) and 84 species (Table 1). Only $8.3 \%$ of these species may be hunted legally in Malta. Ring recoveries represented 31 European countries, four African countries and Russia. Four rings from the island of Crete were recovered, and five from Sicily. The five most commonly recorded countries were Finland (16.5\%), Sweden (11.5\%), Italy (9.4\%), Tunisia (9.2\%) and Germany (6.7\%), which together account for $53.3 \%$ of all recoveries.

The five most common species ringed overseas and shot in Malta were osprey Pandion haliaetus $(n=45)$, common kestrel Falco tinnunculus $(\mathrm{n}=36)$, European turtle dove Streptopelia turtur $(\mathrm{n}=29)$, black-crowned night heron Nycticorax nycticorax $(\mathrm{n}=23)$ and Caspian tern Sterna caspia $(\mathrm{n}=22)$, which comprised $35.6 \%$ of all recoveries. Of these only the European turtle dove may be hunted legally in Malta.

Forty $(47.6 \%)$ of the species recorded were listed as Species of European Conservation Concern by BirdLife International (BirdLife International, 2004). One was categorized as Endangered, one as Vulnerable and five as Near Threatened on the IUCN Red List (IUCN, 2014), and two were categorized as Vulnerable on the European Red Data List (IUCN, 2015).

The most common broad avian groupings (in terms of total number of ring recoveries) were raptors $(22.1 \%)$, waders (19.5\%), gulls \& terns (9.4\%) and herons (8.0\%). As raptors were the most commonly targeted species we considered this group in more detail. Ring recoveries for raptors (of which there were 143 individuals of 18 species recorded in the database) were reported from 17 countries (Fig. 2). The majority of these birds (68.6\%) were ringed as nestlings in their country of origin (predominantly Finland, Sweden and Germany), with a further 10.0\% ringed as juveniles (Table 2).

The most northerly recoveries were from birds ringed in Sweden and Finland. The most southerly recoveries were of a curlew sandpiper Calidris ferruginea and a sanderling Calidris alba, both ringed on the Cape, South Africa.

\section{Discussion}

The analysis has shown that birds from a minimum of 36 countries are affected by hunting in Malta, with the majority of species targeted illegally. 


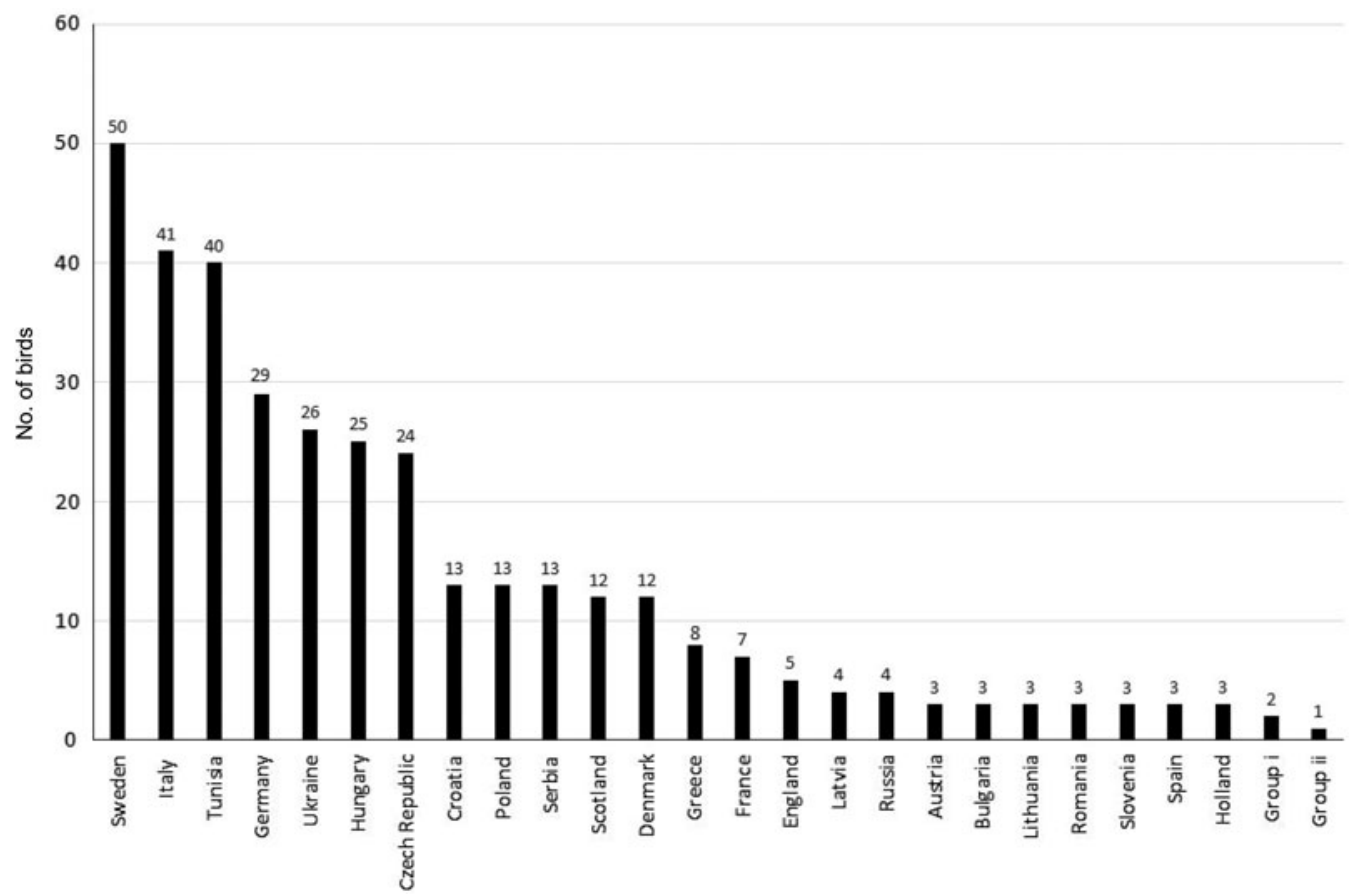

Fig. 1 Numbers of birds ringed overseas and shot in Malta, recorded in the database of the Valletta Bird Ringing Scheme from the 1920 until October 2014. Group 1 comprises Estonia, Norway, Slovakia, Switzerland and South Africa, with two ring recoveries from each, and Group 2 comprises Belgium, Bosnia and Herzegovina, Ireland, Wales, Namibia and Nigeria, with one ring recovery from each.

However, the ringing database underrepresents the number of ringed birds shot, and probably the number of countries of origin, for a number of reasons: a disparity in the level of ringing activity in various countries; the fact that only recoveries reported to BirdLife Malta are recorded, and not those kept by hunters in private illegal collections; the decreasing likelihood of hunters reporting ring recoveries of protected species because of increased scrutiny of the Maltese hunting community; the fact that areas where illegal hunting is prolific are dangerous for members of the public to enter; and hunters regularly hide the carcasses of protected birds they have shot, and leave them to rot or recover them later for taxidermy purposes. The latter is well documented; for example, in September 2009 the carcasses of 213 protected birds that had been shot were found hidden in the woodlands of Mizieb, an area used as a hunting ground by Malta's largest hunting federation, the FKNK (the Federation for Hunting and Conservation; Raine, 2009). The Mizieb woodlands were searched again in 2010 and 2014 and dead protected birds were found hidden throughout the area (Times of Malta, 2014c).

The annexing of public land by hunters is a common occurrence. Hunting occurs at a high density, with c. 47 hunters or trappers per $\mathrm{km}^{2}$ of huntable land, and even more concentrated activity in prime hunting areas (Raine et al., 2009), where hunters actively prevent public access, making it easier to shoot protected species without scrutiny and reducing the likelihood of ring recoveries being reported. This phenomenon has become more accentuated in recent years, with hunting organizations taking members of the public to court in an effort to keep them out of hunting areas. In 2014 the FKNK pressed charges against a member of BirdLife Malta who had been part of a UK film documentary team investigating illegal hunting in the Mizieb and Ahrax woodlands, claiming that the documentary team had been trespassing on what is actually public land (Malta Today, 2014b).

Our analysis has shown that certain countries appear to be particularly affected by illegal hunting activities in Malta. Finland, Sweden and Germany were well represented in the analysis, indicating that illegal hunting in Malta could affect conservation actions being undertaken in these countries, particularly if their breeding populations of the targeted species are small. A significant proportion of recoveries of birds from these countries shot illegally in Malta are birds of prey. The central Mediterranean flyway is particularly important for raptors, with thousands making the crossing every year and passing directly over Malta (Beaman \& Galea, 1974; Sultana \& Gauci, 1982; Coleiro et al., 1995; Garcia \& Arroyo, 1998; Agostini et al., 2003; Sammut \& Bonavia, 2004; Panuccio et al., 2005; Raine, 2011). Many of these birds concentrate in the evening in key roosting areas in Malta, where they are particularly vulnerable to illegal hunting. They are shot as they come in to roost in the late afternoon, or at night under the cover of darkness, by a network of hunters using walkie-talkies to communicate and pinpoint roost sites of rare species. In spring, when flocks of 
TABLE 1 All species listed in the BirdLife Malta database as ringed overseas and shot in the Maltese islands.

\begin{tabular}{|c|c|c|c|}
\hline Species & $\begin{array}{l}\text { No. of ring } \\
\text { recoveries }\end{array}$ & Species & $\begin{array}{l}\text { No. of ring } \\
\text { recoveries }\end{array}$ \\
\hline Osprey Pandion haliaetus & 45 & Ruff Philomachus pugnax & 2 \\
\hline Common kestrel Falco tinnunculus & 36 & Little ringed plover Charadrius dubius & 2 \\
\hline European turtle dove Streptopelia turtur & 29 & Ruddy turnstone Arenaria interpres & 2 \\
\hline Black-crowned night heron Nycticorax nycticorax & 23 & Sanderling Calidris alba & 2 \\
\hline Caspian tern Sterna caspia & 22 & Yellow wagtail Motacilla flava & 2 \\
\hline Western marsh-harrier Circus aeruginosus & 22 & Grey heron Ardea cinerea & 2 \\
\hline Common quail Coturnix coturnix & 17 & European greenfinch Chloris chloris & 2 \\
\hline Black-headed gull Larus ridibundus & 15 & Montagu's harrier Circus pygargus & 2 \\
\hline Mediterranean gull Larus melanocephalus & 13 & Eurasian nightjar Caprimulgus europaeus & 2 \\
\hline European honey buzzard Pernis apivorus & 12 & Pied avocet Recurvirostra avosetta & 1 \\
\hline Barn swallow Hirundo rustica & 12 & Black kite Milvus migrans & 1 \\
\hline Great cormorant Phalacrocorax carbo & 12 & Black redstart Phoenicurus ochruros & 1 \\
\hline Purple heron Ardea purpurea & 11 & Eurasian collared dove Streptopelia decaocto & 1 \\
\hline Great skua Stercorarius skua & 10 & Common chiffchaff Phylloscopus collybita & 1 \\
\hline Lesser black-backed gull Larus fuscus & 8 & Common shelduck Tadorna tadorna & 1 \\
\hline Wood sandpiper Tringa glareola & 8 & Common snipe Gallinago gallinago & 1 \\
\hline Common cuckoo Cuculus canorus & 6 & Garganey Anas querquedula & 1 \\
\hline Common scops-owl Otus scops & 6 & European goldfinch Carduelis carduelis & 1 \\
\hline Eurasian hobby Falco subbuteo & 6 & Great snipe Gallinago media & 1 \\
\hline Dunlin Calidris alpina & 5 & Grey plover Pluvialis squatarola & 1 \\
\hline Sand martin Riparia riparia & 5 & Greylag goose Anser anser & 1 \\
\hline Sandwich tern Sterna sandvicensis & 5 & Gull-billed tern Sterna nilotica & 1 \\
\hline Squacco heron Ardeola ralloides & 5 & Northern house-martin Delichon urbicum & 1 \\
\hline Common starling Sturnus vulgaris & 4 & Kingfisher Alcedo atthis & 1 \\
\hline Eurasian golden oriole Oriolus oriolus & 4 & Lesser kestrel Falco naumanii & 1 \\
\hline Slender-billed gull Larus genei & 4 & Lesser spotted eagle Aquila pomarina & 1 \\
\hline Eleonora's falcon Falco eleonorae & 3 & Eurasian linnet Carduelis cannabina & 1 \\
\hline Eurasian hoopoe Upupa epops & 3 & Pallid harrier Circus macrourus & 1 \\
\hline Little egret Egretta garzetta & 3 & Peregrine falcon Falco peregrinus & 1 \\
\hline Northern gannet Morus bassanus & 3 & European pied flycatcher Ficedula hypoleuca & 1 \\
\hline Common ringed plover Charadrius hiaticula & 3 & Red kite Milvus milvus & 1 \\
\hline European storm petrel Hydrobates pelagicus melitensis & 3 & Red-footed falcon Falco vespertinus & 1 \\
\hline White wagtail Motacilla alba & 3 & European roller Coracias garrulus & 1 \\
\hline Audouin's gull Ichthyaetus audouinii & 2 & Eurasian siskin Carduelis spinus & 1 \\
\hline Collared flycatcher Ficedula albicollis & 2 & Saker falcon Falco cherrug & 1 \\
\hline Common buzzard Buteo buteo & 2 & Sedge warbler Acrocephalus schoenobaenus & 1 \\
\hline Common redshank Tringa totanus & 2 & Short-eared owl Asio flammeus & 1 \\
\hline Common sandpiper Actitis hypoleucos & 2 & Spotted redshank Tringa erythropus & 1 \\
\hline Common swift Apus apus & 2 & Temminck's stint Calidris temminckii & 1 \\
\hline Scopoli's shearwater Calonectris diomedea & 2 & White stork Ciconia ciconia & 1 \\
\hline Curlew sandpiper Calidris ferruginea & 2 & Woodchat shrike Lanius senator & 1 \\
\hline Great reed warbler Acrocephalus arundinaceus & 2 & Yellow-legged gull Larus michahellis & 1 \\
\hline
\end{tabular}

raptors such as Montagu's harrier Circus pygargus and marsh harrier Circus spp. roost in agricultural fields in areas such as Rabat and Delimara, hunters sweep the fields at night with dogs and spotlights, killing every bird they find (Raine, 2011). Consequently, this group of birds is heavily persecuted in Malta, with large numbers killed every year (Sultana \& Gauci, 1982; Coleiro et al., 1995; Sammut \& Bonavia, 2004; Raine, 2011; BirdLife Malta, 2014).

The systematic targeting of birds of prey is evident in the database. Ring recoveries from shot raptors (often in large numbers) include marsh harrier, Montagu's harrier, pallid harrier Circus macrourus, honey buzzard Pernis apivorus, osprey, red-footed falcon Falco vespertinus, common kestrel, lesser kestrel Falco naumanni, hobby Falco subbuteo, peregrine falcon, red kite Milvus milvus and lesser spotted eagle. The effects of illegal persecution on birds of prey are well documented (e.g. Cramp \& Simmons, 1980; Hatsofe, 1981; Del Hoyo et al., 1994; Thirgood et al., 2000; Whitfield et al., 2004; Saurola, 2007). As these species are often rare or declining, have small numbers of young and take several years to reach sexual maturity, the impact of illegal hunting on their populations can have implications for their 


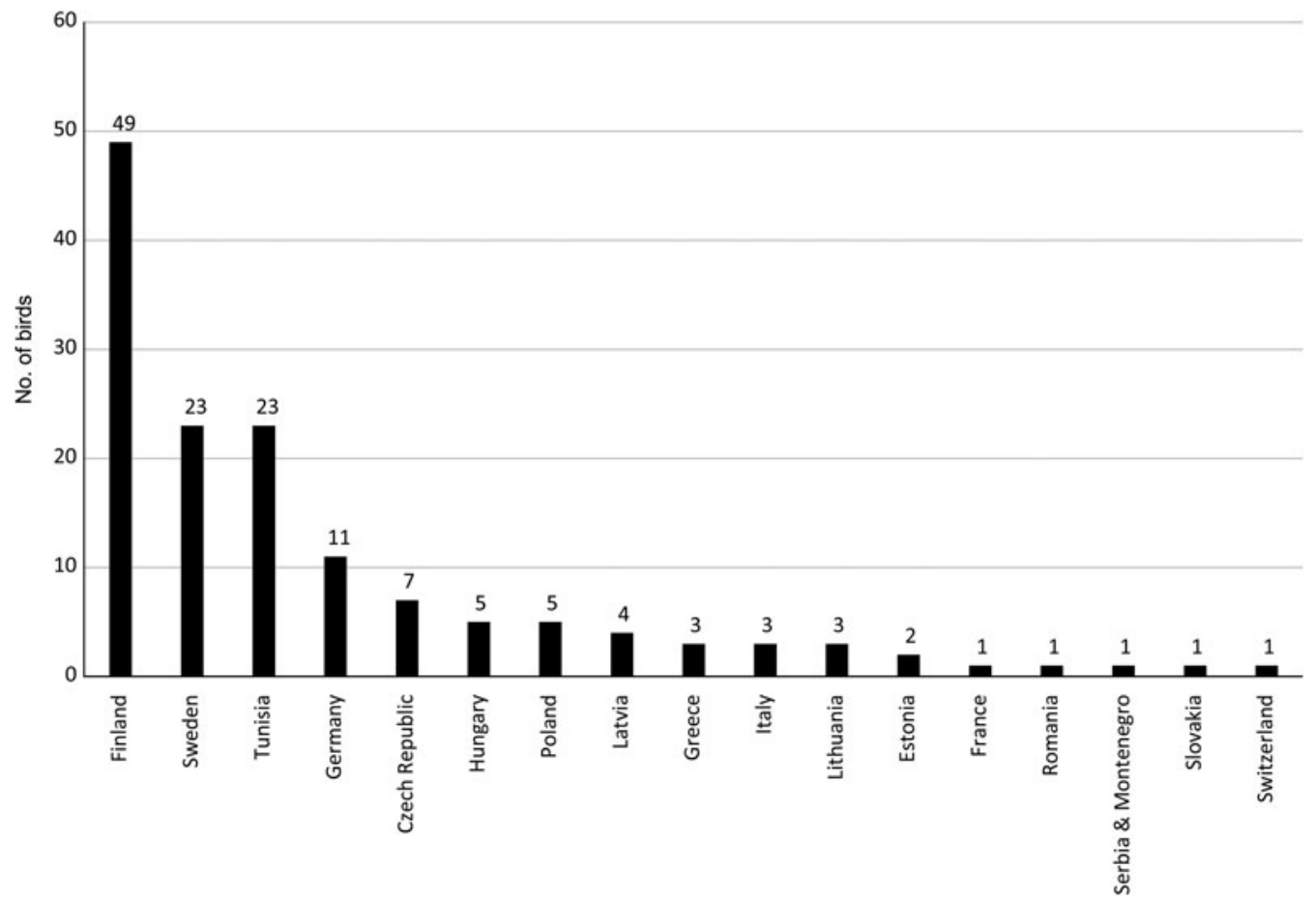

FIG. 2 Numbers of raptors ringed overseas and shot in Malta, recorded in the database of the Valletta Bird Ringing Scheme from the 1920 until October 2014.

conservation status. The peregrine falcon has been extirpated as a breeding bird in Malta despite this species migrating over the islands annually and there being suitable habitat and sufficient food resources available (Raine, 2011; Sultana et al., 2011).

The impact on international conservation efforts is exacerbated by the fact that the majority of larger birds shot in Malta (such as raptors and herons) are juveniles that were ringed as pulli in the nest in their country of origin. Some of these, such as the colour-banded white stork from a reintroduction project in Italy that was shot in 2014, are the output of intensive and expensive reintroduction and conservation efforts in their breeding countries; if the juveniles are subsequently shot down in Malta this effectively negates those conservation efforts. Furthermore, as it takes several years for the young of many of these species to reach sexual maturity, they have to survive several migrations before they are of a sufficient age to breed successfully. For birds that migrate over Malta, the chances of survival to breeding age are reduced by illegal hunting.

Many of these species are of conservation concern in Europe or even globally. Ring recoveries from birds ringed as nestlings or juveniles and killed in Malta include pallid harrier (Near Threatened globally; Endangered in Europe, with a breeding population of 5-51 pairs), osprey (unfavourable conservation status; rare), red-footed falcon (Near Threatened globally; Vulnerable in Europe), saker falcon (Endangered globally; European population 360-540 pairs), lesser spotted eagle (unfavourable conservation status, declining) and purple heron Ardea purpurea (unfavourable conservation status, declining; BirdLife International, 2014).

For many of the species in this analysis ring recoveries were from only a few countries; for example, $97.7 \%$ of osprey recoveries were from Finland and Sweden, with $100.0 \%$ of these ringed as nestlings, and in most cases undertaking their first migration. Satellite tracking of both Swedish and Finnish ospreys confirms the importance of the central European-African migratory route for breeding birds (Hake et al., 2001; Kjellén et al., 2001; FMNH, 2006). Following global declines of this species in the late 1960s (mainly as a result of persecution and the widespread use of the pesticide DDT; Saurola, 1997), the osprey has been the focus of intensive conservation efforts throughout its breeding range and is listed as a species of unfavourable conservation status in Europe, with populations in Finland and Sweden numbering 4,550-5,300 (BirdLife International, 2014). With 45 records of osprey in the database (making it one of the most commonly represented species), and regular reports of unringed birds being shot down every year during migration, the systematic killing of osprey in Malta could have a significant impact on Finnish and Swedish populations of this species.

This is also true for other species, such as the great skua Stercorarius skua, Mediterranean gull Larus melanocephalus and sandwich tern Sterna sandvicensis (the latter designated as being of unfavourable conservation status and depleted in Europe; BirdLife International, 2014). For these 
TABLE 2 Numbers of nestling, juvenile and adult raptors ringed overseas and shot in Malta, recorded in the database of the Valletta Bird Ringing Scheme. (These data were not available for all birds in the database.)

\begin{tabular}{lccc}
\hline Species & Nestling & Juvenile & Adult \\
\hline Black kite & 1 & 1 & \\
Common buzzard & 1 & 7 & 13 \\
Common kestrel & 16 & 2 & \\
Eleonora's falcon & 3 & 1 & 2 \\
European hobby & 3 & 1 & \\
Honey-buzzard & 10 & & \\
Lesser kestrel & & & \\
Lesser spotted eagle & 1 & & \\
Montagu's harrier & 1 & & \\
Osprey & 45 & & \\
Pallid harrier & 1 & & \\
Peregrine falcon & 1 & 2 & 5 \\
Red kite & 1 & & \\
Red-footed falcon & 1 & & \\
Saker falcon & 11 & & \\
Western marsh-harrier & 1 & & \\
Scops-owl & 96 & & \\
Short-eared owl & & & \\
Total & & & \\
\hline
\end{tabular}

species, ring recoveries have been from single countries only. All ring recoveries from great skua $(n=10)$ have been from juveniles that originated in Scotland. With 9,600 pairs, Scotland holds over half of the global population of this species (BirdLife International, 2014). The recovery of shot juveniles in Malta confirms the migratory patterns of this species, with many juveniles leaving Scotland after the breeding season and spending the winter roaming throughout the Mediterranean (Flegg, 2004). For both the Mediterranean gull $(n=13)$ and the sandwich tern $(\mathrm{n}=5)$ all ring recoveries have been from the Ukraine. Illegal hunting of protected species that originate from single countries can have a significant effect on the breeding populations of these species.

For countries with small breeding populations of targeted species, illegal hunting in Malta could ultimately result in the extirpation of the species; for example, key populations of eagles in Europe, which number only a few pairs, could be decimated in the course of a single day's hunting. A satellite-tracked juvenile osprey from a Corsican reintroduction effort went missing after its satellite stopped transmitting after it left an overnight roost site in Delimara in the south of Malta (BirdLife Malta, 2013b). It was assumed to have been shot (although it was not included in the ring recovery analysis as no carcass was found). This was one of only six osprey chicks that fledged in Corsica in 2013.

Many of the raptor species targeted in Malta have small breeding populations in their range countries. A consideration of the various harrier species migrating over Malta represents a good example of this issue as these birds are heavily targeted. Ring recoveries from western marsh harriers include birds from Estonia, Italy and Finland, all with breeding populations in the low hundreds (BirdLife International, 2015a). A ring was recovered from a pallid harrier from Romania, where the population is estimated to be $0-6$ breeding pairs (BirdLife International, 2015b). Two of the three Montagu's harriers from which rings were recovered came from Germany, where there are estimated to be 470-550 breeding pairs (BirdLife International, 2015c). It is apparent that the targeting of these species in Malta could have a significant impact on the small breeding populations in key affected countries.

Malta's hunting laws have been weakened repeatedly, and the hunting lobby granted numerous concessions. This is principally because hunting in Malta is a highly politicized issue (Briguglio, 2014), with the two main political parties alternately courted and threatened by the hunting lobby. General elections are often won by a small margin, and therefore the parties often actively seek the votes of the hunting lobby; for example, in 2003 when Malta was considering joining the European Union the Prime Minister wrote a personal letter to all hunters on the island, assuring them that joining the EU would not affect their hunting and trapping practices (Malta Today, 2013). Hunters will support parties that appear to favour the hunting lobby, and the main hunting lobby, the FKNK, often instructs its members to vote for particular candidates (Malta Today, 2014c).

In 2014, the year after the Labour Party was elected to government after years of a Nationalist government, new concessions were granted to hunters. These included extension of the hunting season; the removal of an afternoon curfew during the peak roosting period for raptors, despite the curfew demonstrably reducing the level of persecution of raptors; allowing hunting on Sundays during the controversial spring hunting season; and allowing finch trapping for the first time in 5 years, with 7,018 trapping sites in operation despite repeated warnings from the European Commission.

The politicization of the issue makes enforcement of hunting laws problematic as neither of the main political parties wants to be perceived as being too strict. At the beginning of the 2014 hunting season the law enforcement unit tasked with dealing with illegal hunting and trapping was weakened, with key long-term personnel reassigned to new units (Times of Malta, 2014d). This ongoing weakening of the hunting laws culminated in widespread illegal hunting activities (which included the shooting of a white stork ringed in Italy, and multiple birds of prey), and the government closed the hunting season on 20 September for a 20day period. There were violent demonstrations by hunters in the capital city, Valletta, on 21 September and local ornithologists were attacked in Buskett Bird Sanctuary, leaving 
two people injured; nine hunters were arrested (Times of Malta, 2014a,b).

Violence against bird watchers and conservationists in Malta is common. A BirdLife Park Ranger was shot and wounded on two separate occasions, in 2007 and 2009 (Malta Independent, 2007; Times of Malta, 2009a) and his farm was burnt down (Times of Malta, 2008a). Bird ringers' cars have been shot at and burned (Times of Malta, 2008b), international volunteers have been assaulted on multiple occasions (Malta Independent, 2010a,b; Malta Today, 2010) and BirdLife Malta Nature Reserves have been vandalized (Times of Malta, 2007a, 2009b). In the most serious incident of vandalism an estimated 3,000 trees in a native reforestation project were cut down overnight (Times of Malta, 2007b) and the same site was attacked 2 years later, with 104 trees cut down. Following the latter incident three hunters were arrested and found guilty (Times of Malta, 2010).

As an example of how locally divisive the issue of hunting is in Malta, a referendum on whether or not a spring hunting season should be allowed to continue was held on the island on 11 April 2015 (BirdLife Malta, 2015a). Spring hunting, which is banned under Article 7(4) of the EU Birds Directive 79/409/EEC, results in an annual spike in illegal hunting incidents as thousands of hunters take to the countryside, with little regulation or enforcement. If the outcome of the referendum had led to the permanent closure of the spring hunting season this would have been a positive step towards controlling illegal hunting during the spring migration period; the benefits were demonstrated when the spring hunting season was closed in 2008 and 2009, with dramatic decreases in illegal hunting incidents during the spring of these two years (Raine \& Temuge, 2009; Raine, 2011). Unfortunately the referendum passed in favour of keeping the spring hunting season, by a narrow margin: $50.4 \%$ in favour, $49.6 \%$ against, with 250,648 votes cast. Reflecting the importance of the debate, the results were the focus of international media attention (e.g. BBC, 2015; EurActive, 2015; Reuters, 2015). Predictably, when the spring hunting season was subsequently opened in 2015 following the referendum, reports of illegal hunting increased, with protected birds shot including common cuckoo and common kestrel (BirdLife Malta, 2015b, 2015c, 2015d). After a kestrel was shot and landed in a football field at St Edward's College, in front of primary school children during their lunch break, the Prime Minister decided to close the spring hunting season early (Malta Today, 2015), highlighting the fact that illegal hunting cannot be controlled adequately during an open hunting season.

Regardless of the outcome of the referendum, spring hunting is still illegal within the European Union, and therefore it is for the European Commission to consider whether or not Malta's choice to have a spring hunting season as a derogation from the Birds Directive is justified. The recent addition of the turtle dove (one of the two species targeted 'legally' during the spring hunting season) to the European Red List (categorized as Vulnerable because of its declining populations throughout Europe) will also need to be taken into consideration (BirdLife International, 2015d). With this new conservation status, a derogation to allow spring hunting in Malta appears even less legally defensible.

Given the international dimension of illegal hunting in Malta, and the conservation status of many of the targeted species, the Maltese government needs to recognize this as an international problem and deal with it accordingly. As a member of the European Union, Malta has a legal obligation to comply with the Birds Directive, the primary European legislation for the protection of wild birds. Migratory species must be protected by robust national legislation that implements the Birds Directive in its entirety. This is not only the responsibility of the Maltese government but also of the European Commission, which must ensure that the laws of the Birds Directive are enforced. Increased fines, custodial sentences for repeat offenders, shorter hunting seasons and effective enforcement are key to controlling the situation. With judges handing out increased fines and several jail sentences in recent years, it appears that this is having a positive effect on reducing illegal hunting activities in some areas. If illegal hunting is brought fully under control in Malta this could have positive ramifications for conservation at a European scale.

\section{Acknowledgements}

We thank Helen Raine, Tolga Temuge, Mark Eaton, Charles Gauci, Joe Sultana, John J. Borg and two anonymous reviewers for their comments and suggestions. We recognize the dedication and contribution of the many BirdLife Malta licensed bird ringers who, through the Valletta Bird Ringing Scheme, have spent so much time and effort over the years carrying out scientific research on Maltese bird migration, often in the face of much adversity.

\section{References}

Agostini, N., Coleiro, C. \& Panuccio, M. (2003) Autumn migration of marsh harriers (Circus aeruginosus) across the central Mediterranean in 2002. The Ring, 25, 47-52.

BBC (2015) Hunters win Malta bird referendum on shooting ban. Http://www.bbc.com/news/world-europe-32274233 [accessed 21 June 2015].

Beaman, M. \& Galea, C. (1974) The visible migration of raptors over the Maltese Islands. Ibis, 116, 419-431.

Birdife International (2004) Birds in Europe: Population Estimates, Trends and Conservation Status. BirdLife International, Cambridge, UK.

BirdLife International (2011) White storks hunted down. Http:// www.birdlife.org/europe-and-central-asia/news/white-storkshunted-down [accessed 13 January 2015]. 
Birdife International (2014) IUCN Red List for Birds. Http:// www.birdlife.org/datazone/sowb/casestudy/106 [accessed 13 January 2015].

BirdLife International (2015a) Western marsh harrier Circus aeruginosus. Http://www.birdlife.org/datazone/speciesfactsheet. php?id=3399 [accessed 1 March 2015].

Birdife International (2015b) Pallid harrier Circus macrourus. Http://www.birdlife.org/datazone/speciesfact sheet.php?id=3409 http://www.birdlife.org [accessed 1 March 2015].

Birdife International (2015c) Circus pygargus (Montagu's Harrier). European Red List of Birds: Supplementary Material. Http://www.birdlife.org/datazone/userfiles/file/Species/erlob/ supplementary pdfs/22695405_circus_pygargus.pdf [accessed 21 June 2015].

BirdLife International (2015d) European Red List of Birds. Office for Official Publications of the European Communities, Luxembourg.

Birdife Malta (2013a) Police and BirdLife guard black storks, but one shot-where was FKNK? Http://www.birdlifemalta.org/media/ press/hunting/view.aspx?id=498\#.VdcqziFwZhE [accessed 13 January 2015].

BirdLife Malta (2013b) BirdLife Malta appeal for information about "missing" satellite tagged osprey. Http://www.birdlifemalta.org/ media/press/conservation/view.aspx?id=494\#.VdcrNiFwZhE [accessed 13 January 2015].

Birdifie Malta (2014) Presumed illegal killing of birds in Malta. Https://wcd.coe.int/com.instranet.InstraServlet?command=com. instranet.CmdBlobGet\&InstranetImage $=2324185 \&$ SecMode $=1 \&$ DocId $=2037586 \&$ Usage $=2$ [accessed 25 May 2015].

Birdlife Malta (2015a) Historic day for Malta and clear win for democracy. Http://www.birdlifemalta.org/media/press/hunting/ view.aspx?id=571\#.VdcrzCFwZhE [accessed 13 January 2015].

Birdife Malta (2015b) Cuckoo shot down on second day of spring hunting season. Http://www.birdlifemalta.org/media/press/ hunting/view.aspx?id=585\#.VdcsCyFwZhE [accessed 21 June 2015].

Birdife Malta (2015c) Shot cuckoo discovered in hunting hotspot. Http://www.birdlifemalta.org/media/press/hunting/view.aspx?id= 587\#.VdcsRSFwZhE [accessed 21 June 2015].

Birdife Malta (2015d) BirdLife Malta welcomes closure of hunting season. Http://www.birdlifemalta.org/media/press/hunting/view. aspx?id=588\#.VdcsfCFwZhE [accessed 21 June 2015]

Briguglio, M. (2014) Bird hunting in European Malta: a case of ENGO empowerment? In Occupy the Earth: Global Environmental Movements (eds L. Leonard \& S.B. Kedzior), pp. 295-324. Emerald Group Publishing Limited, Bingley, UK.

Casha, A. (2004) Where to Watch Birds and Other Wildlife in Malta. BirdLife Malta, Malta.

Coleiro, C., Portelli, P. \& A gostini, N. (1995) Autumn migration of marsh harriers over Malta. Proceedings of the Raptor Research Foundation's Second International Conference on Raptors, 125.

Cramp, S. \& Simmons, K.E.L. (1980) Handbook of the Birds of Europe, the Middle East and North Africa, Volume 2. Hawks to Bustards. Oxford University Press, Oxford, UK.

Del Hoyo, J., Elliot, A. \& Sargatal, J. (1994) Handbook of the Birds of the World. Volume II. Lynx Edicions, Barcelona, Spain.

EurActiv (2015) Referendum fails to put end to Maltese bird hunting tradition. Http://www.euractiv.com/sections/climate-environment/ referendum-puts-end-maltese-bird-hunting-tradition-313715 [accessed 21 June 2015].

Fenech, N. \& Balzan, S. (1988) Last known pair of barn owls Tyto alba shot. Il-Merill, 25, 13-14.

FlegG, J. (2004) Time to Fly: Exploring Bird Migration. British Trust for Ornithology, Thetford, UK.
FMNH (Finnish Museum of Natural History) (2006) Finnish satellite ospreys. Http://www.luomus.fi/en/finnish-satellite-ospreys [accessed 25 May 2015].

Garcia, J. \& Arroyo, B.E. (1998) Migratory movements of western European Montagu's harrier Circus pygargus: a review. Bird Study, $45,188-194$.

Gozo News (2013) Death toll mounts as eagle massacre continues, says BirdLife Malta. Http://gozonews.com/41705/death-tollmounts-as-eagle-massacre-continues-says-birdlife-malta/ [accessed 13 January 2015].

Hake, M., Kjellén, N. \& Alerstam, T. (2001) Satellite tracking of Swedish ospreys Pandion haliaetus: autumn migration routes and orientation. Journal of Avian Biology, 32, 47-56.

Hatsofe, O. (1981) Raptor migration and bird killing in southern Lebanon. Torgos, 1, 25-26.

IUCN (2014) IUCN Red List of Threatened Species. Http://www. iucnredlist.org [accessed 25 May 2015].

IUCN (2015) IUCN European Red List. Http://www.iucnredlist.org/ initiatives/europe [accessed 25 May 2015].

Kjellén, N., Hake, M. \& Alerstam, T. (2001) Timing and speed of migration in male, female and juvenile ospreys Pandion haliaetus between Sweden and Africa as revealed by field observations, radar and satellite tracking. Journal of Avian Biology, 32, 57-67.

Malta Independent (2007) Hunter fires shot at Foresta 2000 ranger. Http://www.independent.com.mt/articles/2007-10-03/news/hunterfires-shot-at-foresta-200o-ranger-blm-197624/ [accessed 25 May 2015].

Malta Independent (2010a) BirdLife Malta volunteer punched in the face in attack. Http://www.independent.com.mt/articles/201008-06/news/birdlife-malta-volunteer-punched-in-the-face-in-attack278334 [accessed 25 May 2015].

Malta Independent (2010b) Court: hunter who attacked CABS official fined $€_{50}$. Http://www.independent.com.mt/articles/201010-21/news/court-hunter-who-attacked-cabs-official-fined-50282012 [accessed 25 May 2015].

Malta Today (2010) Hunters to be charged for assault on CABS volunteers. Http://www.maltatoday.com.mt/news/national/4804/ hunters-to-be-charged-for-assualt-on-cabs-volunteers\#.VQE7avnF-So [accessed 25 May 2015].

Malta Today (2013) Political parties turned Malta into 'hunters' paradise'-BirdLife. Http://www.maltatoday.com.mt/news/ elections2013/23884/political-parties-turned-malta-into-huntersparadise-blm-20130112\#.VPJj4_nF-So [accessed 25 May 2015].

Malta Today (2014a) Shot white stork was part of Italian reintroduction scheme. Http://www.maltatoday.com.mt/lifestyle/ environment/43875/shot_white_stork_was_part_of_italian_ reintroduction_scheme\#.VHkbXTHF-So [accessed 13 January 2015].

Malta Today (2014b) Police charge BirdLife activist who accompanied Packham to Mizieb. Http://www.maltatoday.com.mt/ news/court_and_police/45692/police_charge_birdlife_activist_who_ accompanied_packham_to_mizieb\#.VHkhsjHF-So [accessed 13 January 2015].

MALTA TODAY (2014c) Labour MEPs openly backed by hunting lobby. Http://www.maltatoday.com.mt/news/europe_2014/39311/labour_ meps_openly_backed_by_hunting_lobby\#.VPJjufnF-So [accessed 25 May 2015].

Malta Today (2015) Prime Minister closes spring hunting season after protected bird of prey is shot. Http://www.maltatoday.com.mt/ news/national/52293/shot_bird_falls_into_schools_football_pitch\#. VYdEvflViko [accessed 21 June 2015].

Panuccio, M., Agostini, N. \& Mellone, U. (2005) Autumn migration strategies of honey buzzards, black kites, marsh and 
Montagu's harriers over land and over water in the Central Mediterranean. Avocetta, 29, 27-32.

Raine, A.F. (2009) Report-The Discovery of Dead Protected Birds in Mizieb Woodland, Malta. BirdLife Malta, Ta'Xbiex, Malta.

Raine, A.F. (2011) A Photographic Guide to the Birds of Malta. Langford Press, Peterborough, UK.

Raine, A.F., Sultana, J. \& Gillings, S. (2009) Malta Breeding Bird Atlas 2008. BirdLife Malta, Ta'Xbiex, Malta.

Raine, A.F. \& Temuge, T. (2009) Illegal Hunting Report 2008. BirdLife Malta, Malta.

Raine, A.F. \& Temuge, T. (2010) Illegal Hunting Report 2009. BirdLife Malta, Malta.

Reuters (2015) Malta referendum extends spring bird hunting exception. Http://www.reuters.com/article/2015/04/12/us-maltareferendum-birdhunting-idUSKBNoN309D20150412 [accessed 21 June 2015]

Sammut, M. \& Bonavia, E. (2004) Autumn raptor migration over Buskett, Malta. British Birds, 97, 318-322.

SaUrola, P. (1997) The osprey (Pandion haliaetus) and modern forestry: a review of population trends and their causes in Europe. Journal of Raptor Research, 31, 129-137.

Saurola, P. (2007) Monitoring and conservation of Finnish ospreys (Pandion haliaetus) in 1971-2005. Proceedings of Finnish-Russian Workshop on Birds of Prey, Kostamus, 2005.

Sultana, J., Borg, J.J., Gauci, C. \& Falzon, V. (2011) The Breeding Birds of Malta. BirdLife Malta, Ta'Xbiex, Malta.

Sultana, J. \& Gauci, C. (1982) A New Guide to the Birds of Malta. Malta Ornithological Society, Malta.

Sultana, J. \& GaUCi, C. (1983) Some notes on breeding species for 1982. Il-Merill, 22, 21.

Thirgood, S., Redpath, S., Newton, I. \& Hudson, P. (2000) Raptors and red grouse: conservation conflicts and management solutions. Conservation Biology, 14, 95-104.

Times of Malta (2007a) Vandals strike at Ghadira Nature Reserve. Http://www.timesofmalta.com/articles/view/20070322/local/vandalsstrike-at-ghadira-nature-reserve.22781 [accessed 25 May 2015].

Times of Malta (2007b) Vandals strike at 3,000 pine trees at Mellieha. Http://www.timesofmalta.com/articles/view/20070510/ local/vandals-strike-at-3-ooo-pine-trees-in-mellieha.18397 [accessed 25 May 2015].

Times of Malta (2008a) Environment ranger's farm torched. Http:// www.timesofmalta.com/articles/view/20080602/local/ environment-rangers-farm-torched.210579 [accessed 25 May 2015].

Times of Malta (2008b) Birdwatchers' cars burnt at Buskett. BirdLife demands action. Http://www.timesofmalta.com/articles/ view/20080217/local/updated-birdwatchers-cars-burnt-at-buskettbirdlife-demands-action.19470o [accessed 25 May 2015].

Times of Malta (2009a) Ranger shot in 'ambush'. Http://www. timesofmalta.com/articles/view/20090415/local/ranger-shot-inambush.252877 [accessed 25 May 2015].

Times of Malta (2009b) Break-in at Ghadira Nature Reserve. Http:// www.timesofmalta.com/articles/view/20090121/local/break-in-atghadira-nature-reserve.241578 [accessed 25 May 2015].

Times of Malta (2010) Hunters plead guilty to Foresta 2000 vandalism. Http://www.timesofmalta.com/articles/view/20100824/ local/hunters-plead-guilty-to-foresta-20oo-vandalism.323827 [accessed 25 May 2015].

Times of Malta (2013) Protected stork shot dead by hunters in San Blas. Http://www.timesofmalta.com/articles/view/20130916/local/

Protected-stork-shot-dead-by-hunters-in-San-Blas.486339 [accessed 13 January 2015].

Times of Malta (2014a) Hunters attack birdwatchers in BuskettFKNK condemns incident but "understands hunters' frustrations". Http://www.timesofmalta.com/articles/view/20140921/local/ reactions-hunters-attack-birdwatchers-in-buskett-fknk-condemnsincidents-but-understands-hunters-frustrations.53666o [accessed 13 January 2015].

Times of Malta (2014b) 10 hunters remanded in custody following Sunday's incidents-relatives threaten cameramen. Http://www. timesofmalta.com/articles/view/20140923/local/update-3-10hunters-remanded-in-custody-following-sundays-incidents. 536902 [accessed 13 January 2015].

Times of MALTA (2014c) CABS report finding another 'bird cemetery' in Mizieb. Http://www.timesofmalta.com/articles/view/20140505/ local/cabs-report-finding-another-bird-cemetery-in-mizieb.517759 [accessed 13 January 2015].

Times of Malta (2014d) Environment police unit suffers 'useless massacre'. Http://www.timesofmalta.com/articles/view/20140914/ local/Environment-police-unit-suffers-useless-massacre- .535564 [accessed 13 January 2015].

WBRU (Wild Birds Regulation Unit) (2015) Government publishes autumn 2014 turtle dove and quail migration study report and autumn hunting bag data. Https://environment.gov.mt/en/ government/Press\%2oReleases/Pages/Press\%2oReleases/MAFAR/ 2015/PR150431.aspx [accessed 25 May 2015].

Whitfield, D.P., Fielding, A.H., Mcleod, D.R.A. \& Haworth, P.F. (2004) The effects of persecution on age of breeding and territory occupation in golden eagles in Scotland. Biological Conservation, 118, 249-259.

\section{Biographical sketches}

AndRÉ RaIne worked as the BirdLife Malta Conservation Manager for 4 years during 2007-2011 and was also a member of Malta's Ornis Committee (a consultative body that provides recommendations to government on issues regarding avifauna) during that period. His research interests include bird migration, tracking studies, seabird ecology and the impact of introduced predators on island avifauna. MARK GAUCi has been working as Nature Reserves Manager at BirdLife Malta since 2006. He is the Head of the BirdLife Malta bird ringing scheme, a bird ringer since 1994, and coordinates various local research projects. He occupies the post of avifauna expert with Malta's Ornis Committee. Nicholas B AR B AR A has been working as Conservation Manager at BirdLife Malta since 2012 and is a member of Malta's Ornis Committee. His interests include restoration ecology, conservation of threatened species, and ecosystem management. 